\title{
Lifestyle Changes and Weight-gain in Youth during a 4-Month COVID-19 Lockdown: A Retrospective Observational Study
}

Suixin Liu ( $\sim$ liusuixin@csu.edu.cn )

Division of Cardiac Rehabilitation, Department of Physical Medicine \& Rehabilitation, Xiangya Hospital of Central South University https://orcid.org/0000-0002-4018-4006

Yaoshan Dun

Division of Cardiac Rehabilitation, Department of Physical Medicine \& Rehabilitation, Xiangya Hospital of Central South University

\section{Ripley-Gonzalez Jeffrey}

Division of Cardiac Rehabilitation, Department of Physical Medicine \& Rehabilitation, Xiangya Hospital of Central South University

\section{Nanjiang Zhou}

Division of Cardiac Rehabilitation, Department of Physical Medicine \& Rehabilitation, Xiangya Hospital of Central South University

\section{Baiyang You}

Division of Cardiac Rehabilitation, Department of Physical Medicine \& Rehabilitation, Xiangya Hospital of Central South University

\section{Qiuxia Li}

Division of Cardiac Rehabilitation, Department of Physical Medicine \& Rehabilitation, Xiangya Hospital of Central South University

\section{Hui Li}

Division of Cardiac Rehabilitation, Department of Physical Medicine \& Rehabilitation, Xiangya Hospital of Central South University

\section{Wenliang Zhang}

Division of Cardiac Rehabilitation, Department of Physical Medicine \& Rehabilitation, Xiangya Hospital of Central South University

\section{Randal Thomas}

Division of Preventive Cardiology, Department of Cardiovascular Medicine, Mayo Clinic

\section{Thomas Olson}

Division of Preventive Cardiology, Department of Cardiovascular Medicine, Mayo Clinic Jie Liu

Hunan Traditional Chinese Medical College

\section{Yuchen Dong}




\section{Research Article}

Keywords: COVID-19, SARS-CoV-2, Lockdown, Weight-Gain, Lifestyle Changes

Posted Date: January 19th, 2021

DOl: https://doi.org/10.21203/rs.3.rs-69025/v2

License: (9) This work is licensed under a Creative Commons Attribution 4.0 International License. Read Full License 


\section{Abstract}

Background: The coronavirus disease-2019 (COVID-19) has resulted in nationwide lockdowns, cessation of school and work, and social distancing. Reducing the negative impacts, such as weight-gain, has garnered global attention.

Methods: In this dual-center retrospective observational study of 12,889 students (aged 18-20), who performed a national student physical fitness battery between December 1, 2019, to January 20, 2020, and completed a follow-up online questionnaire beginning on May 1, 2020, and ending on May 23, 2020, and examined the associations between weight-gain and COVID-19 induced stress, depression and selfreported physical activity, dietary habits and sedentary time.

Results: Participants gained an average of $2.6 \mathrm{~kg}(95 \% \mathrm{Cl}: 2.0$ to $3.2 \mathrm{~kg})$ for males and $2.1 \mathrm{~kg}$ (1.9 to 2.4 $\mathrm{kg}$ ) for females. An increase in overweight and obese individuals according to Asian cut-off points as a demographic percentage by $4.5 \%$ and $2.7 \%$ and $4.8 \%$ and $3.4 \%$ in males and females respectively $(P<0.001)$. Weight change was associated with sedentary time, COVID-19 induced stress, and depression score.

Conclusion: These findings suggest that limiting sedentary time during lockdowns and strategies aimed $\mathrm{t}$ improve lifestyle habits and psychological health may be warranted to mitigate weight-gain during the pandemic.

Registration: Registered with ChiCTR, registration no.: ChiCTR2000033514

\section{Introduction}

The sudden emergence of coronavirus disease-2019 (COVID-19) has reverberated the world over, pushing peoples and governments into the unchartered territories of countrywide lockdowns and social distancing. On January 20,2020, China issued a national lockdown as a measure to halt the spread of the deadly virus. While this strategy was largely successful, its negative effects will be of consequence to the health of youth, as for four months they were out of school and for the most part, stuck in the confines of their homes.(1)

Weight-gain compared to stable weight during adolescence and early adulthood is associated with a significantly increased morbidity of diabetes and cardiovascular disease, and an increased risk of cardiovascular and all-cause mortality. $(2,3)$ The increase of weight is a multifactorial matter, yet existing evidence on these factors is largely limited due to a tendency in studies to do a univariate analysis of behaviors on weight-gain. Furthermore, trials that focus on weight loss tend to enlist already obese subjects and intervene with specialized diets attenuating short-term weight loss, limiting the extrapolation of the findings to other populations. Notwithstanding, long-term observational studies and randomized 
controlled trials have found dietary factors, and time spent watching TV were associated with long-term weight-gain in healthy populations. $(4,5)$

Early evidence has shown lockdown poses a real threat to psychological well-being with research citing amplified stress, depression and anxiety in North American, European, and Asian populations. Furthermore, in certain countries there has been a surge in unhealthy dietary habits and increased sedentary time, which could be a recipe for increased weight gain $(6,7)$. Staying at home for a prolonged period could also support a more sedentary lifestyle and increased time watching TV or on other electronic entertainment, along with eating more calorie-dense meals, snacking and alcohol consumption. To date, a limited number of studies have been conducted related to weight change and its associated factors during the COVID-19 lockdown period, and some of those have suggest that behavior change during the pandemic being a driving force behind weight change(6, 7).

This dual-center retrospective observational study assessed weight change during the pandemic lockdown through a multifactorial analysis of associated exposure variables.

\section{Materials And Methods}

\section{Study design and participants}

This retrospective observational study enrolled youth from two universities (Hunan Traditional Chinese Medical College, Hunan, China, and Medical College of Jinhua Polytechnic, Zhejiang, China) that performed the compulsory Chinese National Student Physical Fitness Standard (CNSPFS) battery between December 1, 2019, to January 20,2020, when the government issued sanctioned lockdowns and social distancing and completed a follow-up online questionnaire beginning on May 1, 2020, and ending on May 23, 2020. A total of 14,059 university students who were free of chronic diseases and had completed the CNSPFS were screened. Of these, 13,013 participants (response rate of $93.2 \%$ ) completed the online questionnaire. The participants who replied with questionnaires of poor quality were excluded $(n=124)$. A total of 12,889 participants were finally recruited in the study. All baseline data were extracted from the CNSPFS system, follow-up data were collected from a professional survey platform (https://www.wjx.cn). The criteria of poor quality were: (1) ID information in the CNSPFS system did not match that in the follow-up questionnaire; or (2) The 81 question survey was completed in less than three minutes. This study received ethical approval from the Medical Ethics Committee of Xiangya Hospital, Central South University (REC reference: 202005126). All participants gave electronic consent before enrolment in the study, which was conducted in accord with the principles of the Declaration of Helsinki and participants were anonymized and codified to protect their personal information. 


\section{Characteristics of Lockdown}

The first lockdown order in China was delivered on January 23rd, 2020 by the government of Wuhan, Hubei province, followed by the other cities and provinces of China. The main requirements included: (1) all individuals were ordered to stay home or at their place of residence, except for permitted work, local shopping or other permitted errands, or as otherwise authorized. (2) all schools, sports facilities, entertainment, and recreational venues, personal care and beauty services, and the majority of factories and markets were closed.

During the period of data collection, the participants involved would continue their studies through online learning at the beginning of their second semester of teaching. There were no imminent academic examinations in either time point of data collection.

\section{Weight change}

Baseline weight was assessed by staff members of the two respective universities. This was done in accordance with CNSPFS standards for all university students across China, using scales and after the removal of shoes/coats. Follow-up body weight was obtained via questionnaire. Concerning the determination of follow-up body weight, all participants were asked to measure their body weight in the morning right after waking up, in a state of fasting, shoes off, no large coat. Weight change was calculated by subtracting baseline weight from follow-up weight and the results were verified according to perceived weight change. Weight change was further classified as no significant change ( -0.9 to 0.9 $\mathrm{kg})$, mild decrease $(-3.9$ to $-1.0 \mathrm{~kg})$, moderate decrease $(-6.9$ to $-4.0 \mathrm{~kg})$, major decrease $(\leq-7.0 \mathrm{~kg})$, mild increase $(1.0$ to $3.9 \mathrm{~kg})$, moderate increase $(4.0$ to $6.9 \mathrm{~kg})$, major increase $(\geq 7.0 \mathrm{~kg})$.

\section{Physical activity}

Physical activity was classified as exercise and free-living activity. Exercise habits were collected through questions regarding exercise pre- and post- lockdown, these included frequency, duration, and intensity of aerobic exercise as well as strength exercise, in a modified version with added items of the International Physical Activity Questionnaire-Long form-Chinese (IPAQ-LC), which had shown adequate reliability and reasonable validity for use in Chinese students(8). Exercise volume was expressed in MET-hr/wk, calculated according to the American College of Sports Medicine (ACSM) metabolic equations prior to and during the lockdown.(9) Sedentary time, defined as any waking behavior where energy expenditure is 
$\leq 1.5$ MET's while reclining or sitting, included the number of hours a day spent using a computer or mobile phone(9) and was expressed as $\mathrm{hr} / \mathrm{d}$.

\section{Dietary habits}

In this study, food composition was not assessed due to the high participant burden of such a questionnaire and data collection limitations. The present study evaluated the dietary habits, including breakfast and lunch frequency, alcoholic drinks per week, and snacking times per day. Breakfast and lunch were categorized into three groups: less than once a week, two to six times per week, every day. Snacking was also categorized into three groups: no snacking, snacking once a day (day or late-night), snacking twice per day (day and late-night). Alcohol habits were recorded as the number of drinks, one drink was defined as drinking $100 \mathrm{ml}$ wine or liquor, or $1 \mathrm{glass} /$ bottle/can of beer.

\section{COVID-19 induced stress, depression and anxiety}

The question used to measure COVID-19 induced stress was designed based on previous research(10): How concerned are you about yourself, or family members/friends being infected by COVID-19? To which the possible answers were: None; Mild; Moderate; Major; Severe. Two psychological indexes were also used, Becks' Depression Inventory, second edition (BDI-II)(11) and the State-Trait Anxiety Inventory (STAI) (Form Y-1).(12)

\section{Statistical analysis}

The primary outcome (dependent variable) of the present study was weight change over the lockdown, the independent variables were COVID-19 induced stress, depression, anxiety, physical activity, and dietary habits. Paired $t$-test and Wilcoxon signed-rank test were used for assessment in mean difference between baseline and follow-up of continuous and ordinal variables respectively. The independent relationships of COVID-19 induced stress, depression, anxiety, physical activity, and dietary habits to weight changes within the lockdown, using multivariable linear or binary logistic regression models and accounting for within individual repeated measures were assessed accordingly. Potential nonlinear effects of decreases versus increases in each variable were evaluated by modeling changes in indicator categories, with "no change" as the reference. Multivariable models were used to adjust for sex, age, baseline weight, physical activity, dietary habits, and psychological status simultaneously. To minimize confounding from geolocation and baseline overweight/obesity, university- and BMI-stratified multivariate linear regression were used. Additionally, results were analyzed as relative weight changes (percent), and weight change was a binary variable (weight-gain versus weight loss). Analyses were 
carried out with the use of SAS software, version 9.4 (SAS Institute), a two-tailed alpha level of 0.05 was considered significant.

\section{Results}

\section{Demographics and Weight-gain}

Demographics of 12,889 participants aged $19 \pm 1$ are presented in Table 1. Female subjects were proportionally a larger percentage of the population, which is due to subjects being selected from medical schools largely populated by females. The average weight-gain across the universities was $2.6(95 \% \mathrm{Cl}$, 2.0 to 3.2 ) $\mathrm{kg}$ for males and 2.1 [1.9 to 2.4] $\mathrm{kg}$ for females, while across sex was $4.2 \%$ of baseline body weight. There was a significant increase in overweight and obese individuals as a percentage of the population by $4.5 \%$ and $2.7 \%$ and $4.8 \%$ and $3.4 \%$ in males and females respectively. According to their self-reports, none of the participants of the study were infected with COVID-19. More details are shown in Figure 1 A-E and supplementary Table 1.

\section{Changes in physical activity}

Exercise volumes per week before lockdown were $14.0 \pm 12.3$ and $8.9 \pm 8.3 \mathrm{MET}-\mathrm{hr} / \mathrm{wk}$ in males and females respectively. There was a mild decrease in males (mean [95\% $\mathrm{Cl}$ ], -0.6 [-1.1 to -0.1$]$ ) and increase in females $(2.5[2.3,2.7])$. Sedentary times before lockdown were $6.9 \pm 3.3$ and $7.3 \pm 3.4 \mathrm{hr} /$ day in males and females respectively. There were significant increases in sedentary time both in males (3.9 [3.7 to 4.1]) and females (3.6 [3.5 to 3.7]). More details are shown in Figure 1F and G, and Supplementary Table 1.

\section{Dietary habits}

Males ( $1.8 \pm 2.9$ drinks $)$ drank more than females $(0.7 \pm 1.6$ drinks), the mean difference and $95 \% \mathrm{Cl}$ was 1.2 [1.1 to 1.3]. In contrast, the proportion of females who ate snacks at least once per day was greater than males (females vs. males, $87.9 \%$ vs. $83.2 \%, \mathrm{P}<0.001$ ). Only $33.9 \%$ of males and $32.2 \%$ of females had breakfast every day, no significance was found across sex $(P=0.19)$. In contrast, $98.4 \%$ of males and $98.6 \%$ of females had lunch every day. More details are shown in Supplementary Table 2.

\section{COVID-19 induced stress, depression and anxiety}

More than one-third of all participants (34.6\% of males and $42.4 \%$ of females) suffered COVID- 19 induced stress in different degrees, and $6.9 \%$ of males and $7.4 \%$ of females responded to having severe stress. There was a significant difference in severe COVID-19 induced stress between males and females 
$(P<0.001)$. The depression score obtained from BDI-II were $5 \pm 8$ (mean $\pm \mathrm{SD})$ and $6 \pm 8$ in males and females respectively. The anxiety score using STAI was $39 \pm 10$ both in males and females. More details are shown in Supplementary Table 2.

\section{Relationships between changes in physical activity and weight change}

Sedentary time was independently related to weight change in males ( 0.53 [0.49 to 0.57$] \mathrm{kg}$ ) and females $(0.46$ [0.45 to 0.48$] \mathrm{kg})$. Findings were comparable, in direction and magnitude, for males and females, after stratification for BMI $<24$ and $\geq 24 \mathrm{~kg} / \mathrm{m}^{2}$, and two universities (Table 3, Figure B and C,

Supplementary Table 3-5). Concerning exercise volume, after age and weight adjustment analysis, weight change was negatively associated with an increase in exercise volume in females alone (-0.007 [-0.014 to $-0.000 \mathrm{~kg}$ ). Categorical analyses of sedentary time revealed similar linear relationships that is, aggregate change in sedentary time was robustly related to weight-gain in a dose-dependent fashion, with a $1.56 \mathrm{~kg}$ greater weight-gain across quartiles (Figure 3 ).

\section{Relationships between dietary habits and weight change}

When adjusted for age and baseline weight, snacking frequency per day was positively related to weight change only in females $(0.46[0.21$ to 0.71$] \mathrm{kg})$; alcohol drinks per week was positively associated with weight change in males $(0.03[0.2$ to 0.8$] \mathrm{kg})$, but negatively associated in females $(-0.07$ [ -0.12 to -0.03$]$ $\mathrm{kg})$. In addition, breakfast frequency per week was positively related to the weight-gain only in females $(0.81$ [0.54 to 1.09$] \mathrm{kg})$, lunch breakfast frequency per week only in males (1.52 [0.19 to 2.85] kg). However, after multivariable adjustment, no significant associations were between weight change and dietary habits (not shown).

\section{Relationships of COVID-19 induced stress, depression and anxiety to weight change}

After multivariable adjustment, COVID-19 induced stress was independently related to weight-gain. Compared with those without stress, male and female subjects who suffered severe stress gained 0.88 [0.15 to 1.61$] \mathrm{kg}$ in males and 0.49 [0.13 to 0.82$] \mathrm{kg}$ in females. After stratification for BMI based on the Asian population cut-off $<24^{2}$, two universities, and in analyses when evaluating weight change as an absolute and relative weight change, and as a binary variable (weight again versus weight loss) the results remained consistent (Table 3, Figure 2 A-C, Supplementary Table 3-5). However, the weight of the subjects whose stress is between mild-major had no statistical significance. Depression score was also independently associated with weight change in males $(0.02[0.01$ to 0.05$] \mathrm{kg})$ and females $(0.02$ [0.01 to $0.03] \mathrm{kg}$ ). Across quartiles, participants with a greater increase in depression score gained $0.14 \mathrm{~kg}$ more 
(Figure 2B). There is a significant relationship between anxiety and weight change in females $(0.01$ [0.01 to 0.02$] \mathrm{kg})$, but not in males $(0.01[-0.01$ to 0.03$] \mathrm{kg})$.

\section{Additional Analyses}

All results were similar when evaluated as relative (percent) weight changes rather than absolute weight changes, and when weight change as a binary variable (weight-gain versus weight loss) (Table 3, Figure 2 A-C, Supplementary Table 3-5). Correlations of COVID-19 induced stress to DBI-II depression score, STAI anxiety score, physical activity and dietary habits were generally small $(r<0.05)$.

\section{Discussion}

This is the first multivariate analysis aimed at exploring the burden of imposed lockdowns practices on weight-gain. Longitudinal studies have shown that the average yearly weight-gain in general populations is approximately $0.45 \mathrm{~kg}$ a year.(4). This study has found that over a 4-month lockdown period there was significant weight-gain in the cohort, an average increase of 2.2 [2.2 to 2.3$] \mathrm{kg}$, and an increase in overweight and obese individuals as a percentage of the population by $4.8 \%$ and $3.3 \%$ respectively across sexes in youth $(P<0.001)$. Sharp increases in weight have been associated with an increase in blood pressure.(13) Even more moderate increases over a longer period of time are associated with chronic diseases,(14) all of which are exacerbated when weight is gained during adolescence and early adulthood to have later life repercussions. $(15,16)$ In this study, sedentary time, rather than exercise was significantly associated with weight-gain during the lockdown period, as were other factors, including change in dietary habits, severe COVID-19 induced stress, and depression.

Energy balance and therefore weight-gain is heavily mediated through physical activity. Increased levels of PA, whether as exercise or free-living PA will accordingly increase energy expenditure, any decrease in such will likewise decrease energy expenditure.(17) As an indicator of free-living PA, sedentary time ( $\mathrm{hr} / \mathrm{d})$, including time spent on the computer/phone while sitting, was found to be associated with increased weight, accounting for an average of 0.53 [0.49 to 0.57 ] $\mathrm{kg}$ weight-gain in males and 0.46 [0.45 to $0.48 \mathrm{~kg}$ in females. These findings are consistent with prior research showing sedentary behavior, TV viewing, and computer use being risk factors for increased weight. $(18,19)$ Sedentary behaviors comprise of very little calorific demand.(20) Therefore, they are often the focus of weight loss interventions, as treatment studies have shown that decreases in sedentary times are associated with decreased body fat and weight. Moreover, sedentary time is particularly adverse in the absence of occupational or social cues.(21) Thus, this would be exacerbated during the COVID-19 pandemic and subsequent country-wide lockdown, whereby the populations affected would have limited exposure to outdoor activities, would be out of school or work, and would be generally restricted to their homes. 
Furthermore, in the present paper, self-reported exercise volume decreased modestly in males and increased in females (Figure 1F). The univariate analysis demonstrated that exercise volume was modestly associated with weight change in females alone $(-0.007$ [-0.014 to -0.000$] \mathrm{kg})$, possibly due to the low exercise volume both before (14.0 and 8.8 MET-hr/wk in males and females) and during lockdown (13.4 and 11.3 MET-hr/wk) far below the ACSM-recommended exercise volume (16.7 MET$\mathrm{hr} / \mathrm{wk}),(9)$ and change in exercise volume across sexes being small. Various studies have looked into free-time and PA. While there is some disagreement within population cohorts, in university students it appears that exercise habits are largely mediated by time constraints,(22) where students perceive limited time as a primary reason for not exercising. Also, adherence to exercise is often extrinsic, particularly in youth, where exercisers do so because of physical appearance, weight-gain and stress management adding plausibility that exercise may have been increased as management for perceived weight-gain and/or stress and due to more available time.

Weight-gain also comes through increased intake of calorie-rich food, large portions, and dependent on food composition (23) leading to weight-gain. Several studies have alluded to the significant changes in dietary habits during lockdown. In the UK as many as $48 \%$ of research participants reported increased food intake(24) and increased detrimental dietary practices, echoed throughout western nations and the middle-east $(25,26)$. Although this study did not report on dietary composition, it did investigate dietary habits using four parameters, namely: snacking, breakfast, and lunch frequency and alcohol intake. When adjusted for age and baseline weight, snacking frequency per day was positively related to weight change in females alone $(0.46$ [0.21 to 0.71$] \mathrm{kg})$; while alcohol drinks per week was positively associated with weight change in males $(0.03$ [0.2 to 0.8$] \mathrm{kg})$, but negatively associated in females $(-0.07[-0.12$ to -0.03$]$ $\mathrm{kg}$ ). Moreover, breakfast frequency per week was positively related to the weight-gain only in females and lunch breakfast frequency per week in males only. However, after multivariable adjustment, no significant associations remained between weight change and dietary habits.

Evidence has been accumulating that lockdown conditions have also increased the prevalence of depression, anxiety, and stress across multiple populations.(27) The present study found that severe stress over COVID-19 was associated with a 0.49 [0.13 to 0.82$] \mathrm{kg}$ and 0.88 [0.15 to 1.61$] \mathrm{kg}$ gained weight in females and males respectively. Stressful life events, such as university/school-related stress are known to be associated with weight-gain.(28) Additionally, instances of high to extreme levels of stress can influence eating behaviors, a factor which is more evident with higher severity of stress.(29) Stress is thought to affect PA also, a comprehensive review found the majority of 55 longitudinal studies supported an association between stress and lower levels of PA.(30) However, in our study, the correlation between stress and changes in PA or dietary habits was quite low $(r<0.05)$. (31)

Furthermore, social isolation and confinement are possible routes towards depression.(32) BDI-II depression score was associated with increased body weight in males $(0.02[0.01$ to 0.05$] \mathrm{kg})$ and 
females $(0.02$ [0.01 to 0.03$] \mathrm{kg})$. This is in agreement with a consortium of previous studies, whereby depression appears to have a significant effect on short-term and long-term weight-gain. $(33,34)$ Possibly due to a lack of motivation towards activities that require physical effort such as exercise and increased sedentary time, or the adoption of less healthy eating patterns.or. $(33,35)$ Anxiety was a minimal contributor to weight-gain in females, but not males (Table 2), and appears to be more commonly present in females, which supports previous studies that during the pandemic, state anxiety appears to affect females more than males.(36)

\section{Limitations}

There are a number of limitations to this study. The methods of collecting weight in the two time periods differed, with the first being under supervision of professionals, the second being self administered, due to the constraints of lockdown. While instructions were given to participants regarding how and when to weigh themselves and we had verified this with the weight the self reportedly gained over the period, measurement errors as well as over/under estimation may occur to some degree. Due to limitations in research, we have no data representative of yearly or semesterly weight gain in Chinese university students to compare our results with. Psychological status of depression and anxiety was collected at the second time-point only therefore causality may not be established from these.

Furthermore, just as with any medical intervention or organic finding, the results here represent the average public effect, and variations within individuals exist. The present cohort study only followed up the 4-month lockdown that resulted from the COVID-19 pandemic, and largely comprised Han, universityeducated Chinese youth, which potentially limits the generalizability of the findings. However, our findings were consistent among two universities, sex, and individuals with $\mathrm{BMI}<24$ and $\geq 24 \mathrm{~kg} / \mathrm{m}^{2}$, with multivariable adjustment of age, baseline weight, change in physical activity, dietary habits, psychological status, smoking status. All results remained persistent in additional analyses when evaluated weight change as relative (percent) weight changes rather than absolute weight changes, and when weight change as a binary variable. It seems plausible that the biologic effects of many factors would be qualitatively similar in other populations.

\section{Conclusion}

The COVID -19 lockdown appeared to have a more pronounced effect on sedentary time than on exercise. In this study, weight gain was accordingly predicted by increased sedentary time rather than decreased exercise. Furthermore, severe COVID-19 induced stress, depression were mutually independently associated with weight-gain during a 4-month lockdown period, but causality cannot be established. These findings suggest that lockdowns promote sedentary time, and that strategies to improve lifestyle habits and psychological health may be warranted to mitigate weight-gain. 


\section{Declarations}

\section{Conflicts of interests}

The authors declare that the research was conducted in the absence of any commercial or financial relationships that could be construed as a potential conflict of interest.

\section{Authors contributions}

SXL, YSD and JWR conceived the study. SXL and YSD were involved in securing funding for the study. NJZ, BYY, WLZ, YCD, JL, HL and QXL coordinated the study conduct and data collection. YSD and SYX did the study analyses, supervised by SXL. YSD and JWR wrote the article, with assistance from RJT, TPO, BYY, QXL, HL and SXL. All authors approved the final version of the manuscript. SXL had full access to all the data in the study and had final responsibility for the decision to submit for publication.

\section{Funding}

This study is supported by Hunan Development and Reform Commission Foundation of China (No. [2012]1521 to SXL) and The Youth Science Foundation of Xiangya Hospital (Grant number 2019Q03 to YSD).

\section{Ethics}

This study received ethical approval from the Medical Ethics Committee of Xiangya Hospital, Central South University (REC reference: 202005126). All participants gave consent before enrolment in the study, which was conducted in accord with the principles of the Declaration of Helsinki.

\section{Acknowledgements}

We would like to thank all participants and investigators in participating centers. We would also like to thank Jiabi Qin and Jing Deng (Xiangya School of Public Health, Central South University, Hunan, China), who provided advice on the statistical analysis plan.

\section{References}

1. King AJ, Burke LM, Halson SL, Hawley JA. The Challenge of Maintaining Metabolic Health During a Global Pandemic. Sports Med (2020):1-9. doi: 10.1007/s40279-020-01295-8. 
2. Yang Y, Dugue PA, Lynch BM, Hodge AM, Karahalios A, Maclnnis RJ, et al. Trajectories of body mass index in adulthood and all-cause and cause-specific mortality in the Melbourne Collaborative Cohort Study. BMJ Open (2019) 9(8):e030078. doi: 10.1136/bmjopen-2019-030078.

3. Zheng Y, Manson JE, Yuan C, Liang MH, Grodstein F, Stampfer MJ, et al. Associations of Weight Gain From Early to Middle Adulthood With Major Health Outcomes Later in Life. JAMA (2017) 318(3):25569. doi: 10.1001/jama.2017.7092.

4. Mozaffarian D, Hao T, Rimm EB, Willett WC, Hu FB. Changes in diet and lifestyle and long-term weight gain in women and men. N Engl J Med(2011) 364(25):2392-404. doi:

10.1056/NEJMoa1014296.

5. Raynor HA, Steeves EA, Bassett DR, Jr., Thompson DL, Gorin AA, Bond DS. Reducing TV watching during adult obesity treatment: two pilot randomized controlled trials. Behav Ther(2013) 44(4):67485. doi: 10.1016/j.beth.2013.04.012.

6. Kriaucioniene V, Bagdonaviciene L, Rodriguez-Perez C, Petkeviciene J. Associations between Changes in Health Behaviours and Body Weight during the COVID-19 Quarantine in Lithuania: The Lithuanian COVIDiet Study. Nutrients (2020) 12(10). doi: 10.3390/nu12103119.

7. Flanagan EW, Beyl RA, Fearnbach SN, Altazan AD, Martin CK, Redman LM. The impact of COVID-19 stay-at-home orders on health behaviors in adults. Obesity (Silver Spring, Md) (2020). doi: 10.1002/oby. 23066 .

8. Macfarlane D, Chan A, Cerin E. Examining the validity and reliability of the Chinese version of the International Physical Activity Questionnaire, long form (IPAQ-LC). Public Health Nutr (2011) 14(3):443-50. doi: 10.1017/S1368980010002806.

9. Riebe D, Ehrman JK, Liguori G, Magal M. ACSM's guidelines for exercise testing and prescription: Philadelphia : Wolters Kluwer, [2018] @2018 (2018).

10. Goodwin R, Gaines SO, Jr., Myers L, Neto F. Initial psychological responses to swine flu. Int J Behav Med (2011) 18(2):88-92. doi: 10.1007/s12529-010-9083-z.

11. Beck AT, Steer RA, Brown GK. Manual for the Beck depression inventory-II. Psychological Corporation (1996) 1996:1-82.

12. Spielberger CD, Gorsuch R, Lushene RE, Vagg P, Jacobs GA. Manual for the State-Trait Anxiety Inventory (Form Y1 - Y2)(1983).

13. Covassin N, Sert-Kuniyoshi FH, Singh P, Romero-Corral A, Davison DE, Lopez-Jimenez F, et al. Experimental Weight Gain Increases Ambulatory Blood Pressure in Healthy Subjects: Implications of Visceral Fat Accumulation. Mayo Clin Proc (2018) 93(5):618-26. doi:

10.1016/j.mayocp.2017.12.012.

14. Lv J, Fan B, Wei M, Zhou G, Dayimu A, Wu Z, et al. Trajectories of early to mid-life adulthood BMI and incident diabetes: the China Health and Nutrition Survey. BMJ Open Diabetes Res Care (2020) 8(1):e000972. doi: 10.1136/bmjdrc-2019-000972.

15. van der Baan-Slootweg O, Benninga MA, Beelen A, van der Palen J, Tamminga-Smeulders C, Tijssen JG, et al. Inpatient treatment of children and adolescents with severe obesity in the Netherlands: a 
randomized clinical trial. JAMA Pediatr (2014) 168(9):807-14. doi:

10.1001/jamapediatrics.2014.521.

16. Daniels SR, Pratt CA, Hayman LL. Reduction of risk for cardiovascular disease in children and adolescents. Circulation (2011) 124(15):1673-86. doi: 10.1161/CIRCULATIONAHA.110.016170.

17. Westerterp KR. Control of energy expenditure in humans. Eur J Clin Nutr (2017) 71(3):340-4. doi: 10.1038/ejcn.2016.237.

18. Ashdown-Franks G, Vancampfort D, Firth J, Veronese N, Jackson SE, Smith L, et al. Leisure-Time Sedentary Behavior and Obesity Among 116,762 Adolescents Aged 12-15 Years from 41 Low- and Middle-Income Countries. Obesity (Silver Spring, Md) (2019) 27(5):830-6. doi: 10.1002/oby.22424.

19. Guo C, Zhou Q, Zhang D, Qin P, Li Q, Tian G, et al. Association of total sedentary behaviour and television viewing with risk of overweight/obesity, type 2 diabetes and hypertension: A dose-response meta-analysis. Diabetes, obesity \& metabolism (2020) 22(1):79-90. doi: 10.1111/dom.13867.

20. Bonn SE, Rimm EB, Matthews CE, Troiano RP, Bowles HR, Rood J, et al. Associations of Sedentary Time with Energy Expenditure and Anthropometric Measures. Medicine and science in sports and exercise (2018) 50(12):2575-83. doi: 10.1249/mss.0000000000001729.

21. Pietrobelli A, Pecoraro L, Ferruzzi A, Heo M, Faith M, Zoller T, et al. Effects of COVID-19 Lockdown on Lifestyle Behaviors in Children with Obesity Living in Verona, Italy: A Longitudinal Study. Obesity (Silver Spring, Md) (2020). doi: 10.1002/oby.22861.

22. Ebben W, Brudzynski L. Motivations and barriers to exercise among college students. Journal of Exercise Physiology Online (2008) 11:1-11.

23. Zhou B, Ichikawa R, Parnell LD, Noel SE, Zhang X, Bhupathiraju SN, et al. Metabolomic Links between Sugar-Sweetened Beverage Intake and Obesity. Journal of obesity (2020) 2020:7154738. doi: $10.1155 / 2020 / 7154738$.

24. Buckland NJ, Swinnerton LF, Ng K, Price M, Wilkinson LL, Myers A, et al. Susceptibility to increased high energy dense sweet and savoury food intake in response to the COVID-19 lockdown: The role of craving control and acceptance coping strategies. Appetite (2021) 158:105017. doi:

10.1016/j.appet.2020.105017.

25. Cheikh Ismail L, Osaili TM, Mohamad MN, Al Marzouqi A, Jarrar AH, Abu Jamous DO, et al. Eating Habits and Lifestyle during COVID-19 Lockdown in the United Arab Emirates: A Cross-Sectional Study. Nutrients (2020) 12(11). doi: 10.3390/nu12113314.

26. Di Renzo L, Gualtieri P, Pivari F, Soldati L, Attina A, Cinelli G, et al. Eating habits and lifestyle changes during COVID-19 lockdown: an Italian survey. J Trans/ Med(2020) 18(1):229. doi: 10.1186/s12967020-02399-5.

27. Brooks SK, Webster RK, Smith LE, Woodland L, Wessely S, Greenberg N, et al. The Psychological Impact of Quarantine and How to Reduce It: Rapid Review of the Evidence. Lancet (2020) 395(10227):912-20. doi: 10.1016/S0140-6736(20)30460-8.

28. Serlachius A, Hamer M, Wardle J. Stress and weight change in university students in the United Kingdom. Physiol Behav (2007) 92(4):548-53. doi: 10.1016/j.physbeh.2007.04.032. 
29. Torres SJ, Nowson CA. Relationship between stress, eating behavior, and obesity. Nutrition (2007) 23(11-12):887-94. doi: 10.1016/j.nut.2007.08.008.

30. Stults-Kolehmainen MA, Sinha R. The effects of stress on physical activity and exercise. Sports Med (2014) 44(1):81-121. doi: 10.1007/s40279-013-0090-5.

31. van der Valk ES, Savas M, van Rossum EFC. Stress and Obesity: Are There More Susceptible Individuals? Curr Obes Rep (2018) 7(2):193-203. doi: 10.1007/s13679-018-0306-y.

32. Matthews T, Danese A, Wertz J, Odgers CL, Ambler A, Moffitt TE, et al. Social isolation, loneliness and depression in young adulthood: a behavioural genetic analysis. Soc Psychiatry Psychiatr Epidemiol (2016) 51(3):339-48. doi: 10.1007/s00127-016-1178-7.

33. Konttinen H, van Strien T, Mannisto S, Jousilahti P, Haukkala A. Depression, emotional eating and long-term weight changes: a population-based prospective study. Int J Behav Nutr Phys Act (2019) 16(1):28. doi: 10.1186/s12966-019-0791-8.

34. Grundy A, Cotterchio M, Kirsh VA, Kreiger N. Associations between anxiety, depression, antidepressant medication, obesity and weight gain among Canadian women. PLoS One (2014) 9(6):e99780. doi: 10.1371/journal.pone.0099780.

35. Wurtman JJ. Depression and weight gain: the serotonin connection. J Affect Disord (1993) 29(23):183-92. doi: 10.1016/0165-0327(93)90032-f.

36. Wang C, Pan R, Wan X, Tan Y, Xu L, Ho CS, et al. Immediate Psychological Responses and Associated Factors during the Initial Stage of the 2019 Coronavirus Disease (COVID-19) Epidemic among the General Population in China. Int J Environ Res Public Health (2020) 17(5):1729. doi: 10.3390/ijerph17051729.

\section{Tables}

Table 1. Demographics and baseline characteristics 


\begin{tabular}{|c|c|c|c|c|c|c|}
\hline & \multicolumn{2}{|c|}{$\begin{array}{l}\text { University } 1(\mathrm{~N}=9,472) \\
\S\end{array}$} & \multicolumn{2}{|c|}{$\begin{array}{l}\text { University } 2(\mathrm{~N}=3,417) \\
\S\end{array}$} & \multicolumn{2}{|c|}{ Total $(\mathrm{N}=12,889)$} \\
\hline & $\begin{array}{l}\text { Males } \\
(\mathrm{N}= \\
1,509)\end{array}$ & $\begin{array}{l}\text { Females } \\
(\mathrm{N}=7,963)\end{array}$ & $\begin{array}{l}\text { Males }(N= \\
1,040)\end{array}$ & $\begin{array}{l}\text { Females } \\
(\mathrm{N}= \\
2,377)\end{array}$ & $\begin{array}{l}\text { Males } \\
(\mathrm{N}= \\
2,549)\end{array}$ & $\begin{array}{l}\text { Females } \\
(\mathrm{N}= \\
10,340)\end{array}$ \\
\hline Age, yr & $19 \pm 1$ & $19 \pm 1$ & $20 \pm 1$ & $20 \pm 1$ & $20 \pm 1$ & $19 \pm 1$ \\
\hline Weight, kg & $\begin{array}{l}62.3 \pm \\
10.2\end{array}$ & $52.0 \pm 7.8$ & $65.0 \pm 10.3$ & $\begin{array}{l}52.2 \pm \\
7.6\end{array}$ & $\begin{array}{l}63.4 \pm \\
10.3\end{array}$ & $\begin{array}{l}52.0 \pm \\
7.7\end{array}$ \\
\hline $\begin{array}{l}\text { Body mass index, } \\
\mathrm{kg} / \mathrm{m}^{2}\end{array}$ & $\begin{array}{l}21.0 \pm \\
3.2\end{array}$ & $20.3 \pm 2.7$ & $21.4 \pm 3.1$ & $\begin{array}{l}20.1 \pm \\
2.5\end{array}$ & $\begin{array}{l}21.2 \pm \\
3.2\end{array}$ & $\begin{array}{l}20.2 \pm \\
2.7\end{array}$ \\
\hline Overweight, n (\%)ฯ & $\begin{array}{l}214 \\
(14.5)\end{array}$ & $\begin{array}{l}1,370 \\
(17.2)\end{array}$ & $83(8.0)$ & $\begin{array}{l}140 \\
(5.9)\end{array}$ & $\begin{array}{l}297 \\
(11.7)\end{array}$ & $\begin{array}{l}1,510 \\
(14.6)\end{array}$ \\
\hline Obesity, n (\%)ฯ & $57(3.8)$ & $263(3.3)$ & $17(1.6)$ & $36(1.5)$ & $74(2.9)$ & $299(2.9)$ \\
\hline \multicolumn{7}{|l|}{ Race/ethnicity, n (\%) } \\
\hline Han & $\begin{array}{l}1,305 \\
(86.5)\end{array}$ & $\begin{array}{l}6,872 \\
(86.3)\end{array}$ & $1,040(100)$ & $\begin{array}{l}2,377 \\
(100)\end{array}$ & $\begin{array}{l}2,345 \\
(92.0)\end{array}$ & $\begin{array}{l}9,249 \\
(89.4)\end{array}$ \\
\hline Non-Han & $\begin{array}{l}204 \\
(13.5)\end{array}$ & $1,091(13.7)$ & $0(0)$ & $0(0)$ & $\begin{array}{l}204 \\
(8.0)\end{array}$ & $\begin{array}{l}1,091 \\
(10.6)\end{array}$ \\
\hline $\begin{array}{l}\text { Physical activity, } \\
\text { MET-hr/wk }\end{array}$ & $\begin{array}{l}14.2 \\
\pm 12.5\end{array}$ & $9.1 \pm 8.5$ & $13.7 \pm 12.2$ & $7.7 \pm 7.3$ & $\begin{array}{l}14.0 \pm \\
12.3\end{array}$ & $8.9 \pm 8.3$ \\
\hline $\begin{array}{l}\text { Sedentary time, } \\
\text { hr/day }\end{array}$ & $6.9 \pm 3.4$ & $7.3 \pm 3.4$ & $7.0 \pm 3.2$ & $\begin{array}{l}7.3 \pm \\
3.3\end{array}$ & $\begin{array}{l}6.9 \pm \\
3.3\end{array}$ & $7.3 \pm 3.4$ \\
\hline \multicolumn{7}{|l|}{ Smoking, n (\%) } \\
\hline Currently smoking & $\begin{array}{l}294 \\
(19.5)\end{array}$ & $77(1.0)$ & $96(9.2)$ & $9(0.4)$ & $\begin{array}{l}390 \\
(15.3)\end{array}$ & $86(0.9)$ \\
\hline$<10$ cigarettes/day & $\begin{array}{l}220 \\
(14.6)\end{array}$ & $66(0.8)$ & $77(7.4)$ & $7(0.3)$ & $\begin{array}{l}297 \\
(11.7)\end{array}$ & $73(0.7)$ \\
\hline 10-15 cigarettes/day & $45(3.0)$ & $8(0.1)$ & $12(1.1)$ & $1(0.04)$ & $57(2.2)$ & $9(0.09)$ \\
\hline >15 cigarettes/day & $29(1.9)$ & $3(0.1)$ & $7(0.7)$ & $1(0.04)$ & $36(1.4)$ & $4(0.03)$ \\
\hline Former smoker & $\begin{array}{l}165 \\
(10.9)\end{array}$ & $130(1.6)$ & $62(6.0)$ & $17(0.7)$ & $\begin{array}{l}227 \\
(8.9)\end{array}$ & $147(1.4)$ \\
\hline Never smoke & $\begin{array}{l}1,050 \\
(69.6)\end{array}$ & $\begin{array}{l}7,756 \\
(97.4)\end{array}$ & $882(84.8)$ & $\begin{array}{l}2,351 \\
(98.9)\end{array}$ & $\begin{array}{l}1932 \\
(75.8)\end{array}$ & $\begin{array}{l}10,107 \\
(97.7)\end{array}$ \\
\hline
\end{tabular}

Data were expressed as mean \pm standard deviation or number (percent) accordingly. 
- University 1 was Hunan Traditional Chinese Medical College, Hunan province, China; University 2 was Jinhua Polytechnic, Zhejiang province, China.

9 Overweight and obesity cut-off point were referred to Asian criteria, overweight is BMI $\geq 24$ and $<28$ $\mathrm{kg} / \mathrm{m}^{2}$, and obesity $\mathrm{BMI} \geq 28 \mathrm{~kg} / \mathrm{m}^{2}$.

Table 2. Pooled, age- and baseline weight-adjusted results for the relationships of psychological status, change in physical activity and dietary habits to weight change during a 4-month lockdown. 


\begin{tabular}{|c|c|c|c|c|c|c|}
\hline & Males $(\mathrm{N}=2,54$ & & Females $(\mathrm{N}=10$ & & Total $(\mathrm{N}=12,889$ & \\
\hline & $\begin{array}{l}\text { Weight Change } \\
(\mathrm{kg})\end{array}$ & $\begin{array}{l}\mathrm{P} \\
\text { Value }\end{array}$ & $\begin{array}{l}\text { Weight Change } \\
(\mathrm{kg})\end{array}$ & $\begin{array}{l}\mathrm{P} \\
\text { Value }\end{array}$ & $\begin{array}{l}\text { Weight Change } \\
(\mathrm{kg})\end{array}$ & $\begin{array}{l}\mathrm{P} \\
\text { Value }\end{array}$ \\
\hline & Mean $(95 \% \mathrm{Cl})$ & & Mean $(95 \% \mathrm{Cl})$ & & Mean $(95 \% \mathrm{Cl})$ & \\
\hline $\begin{array}{l}\text { Psychological } \\
\text { status }\end{array}$ & & & & & & \\
\hline COVID-19 induced & tress & & & & & \\
\hline None & Reference & & Reference & & Reference & \\
\hline Mild & 0.450 & 0.12 & 0.153 & 0.30 & 0.192 & 0.08 \\
\hline & $\begin{array}{l}(-0.075 \text { to } \\
0.975)\end{array}$ & & $\begin{array}{l}(-0.069 \text { to } \\
0.375)\end{array}$ & & $\begin{array}{l}(-0.013 \text { to } \\
0.398)\end{array}$ & \\
\hline Moderate & -0.004 & 0.99 & 0.282 & 0.13 & 0.225 & 0.24 \\
\hline & $\begin{array}{l}(-0.774 \text { to } \\
0.767)\end{array}$ & & $\begin{array}{l}(-0.050 \text { to } \\
0.614)\end{array}$ & & $\begin{array}{l}(-0.080 \text { to } \\
0.532)\end{array}$ & \\
\hline Major & 0.551 & 0.52 & 0.339 & 0.15 & 0.362 & 0.07 \\
\hline & $\begin{array}{l}(-0.449 \text { to } \\
1.551)\end{array}$ & & $\begin{array}{l}(-0.074 \text { to } \\
0.752)\end{array}$ & & $\begin{array}{l}(-0.022 \text { to } \\
0.746)\end{array}$ & \\
\hline Severe & 1.116 & 0.001 & 0.521 & $<$ & 0.619 & $<$ \\
\hline & $\begin{array}{l}(0.339 \text { to } \\
1.892)\end{array}$ & & $\begin{array}{l}(0.176 \text { to } \\
0.865)\end{array}$ & & $\begin{array}{l}(0.303 \text { to } \\
0.935)\end{array}$ & \\
\hline Depression score & 0.034 & $<$ & 0.024 & $<$ & 0.025 & $<$ \\
\hline & $\begin{array}{l}(0.015 \text { to } \\
0.052)\end{array}$ & & $\begin{array}{l}(0.015 \text { to } \\
0.032)\end{array}$ & & $\begin{array}{l}(0.017 \text { to } \\
0.033)\end{array}$ & \\
\hline Anxiety score & 0.014 & 0.08 & 0.011 & 0.003 & 0.012 & $<$ \\
\hline & $\begin{array}{l}(-0.001 \text { to } \\
0.029)\end{array}$ & & $\begin{array}{l}(0.004 \text { to } \\
0.018)\end{array}$ & & $\begin{array}{l}(0.005 \text { to } \\
0.018)\end{array}$ & \\
\hline Changes in physic & activity & & & & & \\
\hline Sedentary time, & 0.504 & $<$ & 0.457 & $<$ & 0.468 & $<001$ \\
\hline & $\begin{array}{l}(0.466 \text { to } \\
0.542)\end{array}$ & & $\begin{array}{l}(0.440 \text { to } \\
0.475)\end{array}$ & & $\begin{array}{l}(0.452 \text { to } \\
0.484)\end{array}$ & \\
\hline Exercise volume, & -0.003 & 0.59 & -0.007 & 0.04 & -0.008 & 0.01 \\
\hline MET-hr/wk & $\begin{array}{l}(-0.015 \text { to } \\
0.008)\end{array}$ & & $\begin{array}{l}(-0.014 \text { to } \\
0.000)\end{array}$ & & $\begin{array}{l}(-0.002 \text { to } \\
-0.013)\end{array}$ & \\
\hline Dietary habits & & & & & & \\
\hline Alcohol, & 0.023 & 0.01 & -0.072 & $<$ & -0.007 & 0.009 \\
\hline
\end{tabular}




\begin{tabular}{|c|c|c|c|c|c|c|}
\hline drinks/wk & $\begin{array}{l}(-0.029 \text { to } \\
0.075)\end{array}$ & & $\begin{array}{l}(-0.115 \text { to } \\
-0.028)\end{array}$ & 0.001 & $\begin{array}{l}(-0.039 \text { to } \\
0.025)\end{array}$ & \\
\hline \multicolumn{7}{|l|}{ Snacking 9} \\
\hline No & Reference & & Reference & & Reference & \\
\hline \multirow[t]{2}{*}{ Day or late-night } & 0.189 & 0.57 & 0.391 & 0.001 & 0.302 & 0.005 \\
\hline & $\begin{array}{l}(-0.303 \text { to } \\
0.680)\end{array}$ & & $\begin{array}{l}(0.143 \text { to } \\
0.639)\end{array}$ & & $\begin{array}{l}(0.082 \text { to } \\
0.523)\end{array}$ & \\
\hline \multirow{2}{*}{$\begin{array}{l}\text { Day and late- } \\
\text { night }\end{array}$} & 0.383 & 0.14 & 0.456 & $<001$ & 0.410 & $<001$ \\
\hline & $\begin{array}{l}(-0.101 \text { to } \\
0.867)\end{array}$ & & $\begin{array}{l}(0.205 \text { to } \\
0.707)\end{array}$ & & $\begin{array}{l}(0.187 \text { to } \\
0.633)\end{array}$ & \\
\hline \multicolumn{7}{|c|}{ Breakfast frequency/wk 9} \\
\hline Less than once & Reference & & Reference & & Reference & \\
\hline \multirow[t]{2}{*}{ Two to six } & -0.005 & 0.99 & 0.514 & $<$ & 0.415 & $<001$ \\
\hline & $\begin{array}{l}(-0.574 \text { to } \\
0.564)\end{array}$ & & $\begin{array}{l}(0.252 \text { to } \\
0.775)\end{array}$ & & $\begin{array}{l}(0.176 \text { to } \\
0.654)\end{array}$ & \\
\hline \multirow[t]{2}{*}{ Every day } & 0.131 & 0.80 & 0.813 & $<$ & 0.685 & $<$ \\
\hline & $\begin{array}{l}(-0.466 \text { to } \\
0.728)\end{array}$ & & $\begin{array}{l}(0.536 \text { to } \\
1.090)\end{array}$ & & $\begin{array}{l}(0.433 \text { to } \\
0.937)\end{array}$ & \\
\hline \multicolumn{7}{|l|}{$\begin{array}{l}\text { Lunch } \\
\text { frequency/wk }\end{array}$} \\
\hline Less than once & Reference & & Reference & & Reference & \\
\hline \multirow[t]{2}{*}{ Two to six } & 1.521 & 0.02 & 0.473 & 0.14 & 0.644 & 0.03 \\
\hline & $\begin{array}{l}(0.188 \text { to } \\
2.853)\end{array}$ & & $\begin{array}{l}(-0.152 \text { to } \\
1.100)\end{array}$ & & $\begin{array}{l}(0.076 \text { to } \\
1.214)\end{array}$ & \\
\hline \multirow[t]{2}{*}{ Every day } & 1.07 & 0.11 & 0.535 & 0.09 & 0.648 & 0.02 \\
\hline & $\begin{array}{l}(-0.223 \text { to } \\
2.361)\end{array}$ & & $\begin{array}{l}(-0.079 \text { to } \\
1.151)\end{array}$ & & $\begin{array}{l}(0.092 \text { to } \\
1.206)\end{array}$ & \\
\hline
\end{tabular}

१ The first level of the ordered categorical variables were used as reference.

Table 3. Pooled, multivariable-adjusted results for the relationships of COVID-19 induced stress, change in sedentary time and depression score to weight change during a 4-month lockdown. 


\begin{tabular}{|c|c|c|c|c|c|c|}
\hline & \multicolumn{2}{|c|}{ Males $(\mathrm{N}=2,549)$} & \multicolumn{2}{|c|}{ Females $(N=10,340)$} & \multicolumn{2}{|c|}{ Total $(\mathrm{N}=12,889)$} \\
\hline & $\begin{array}{l}\text { Weight } \\
\text { Change (kg) }\end{array}$ & $\begin{array}{l}\mathrm{P} \\
\text { Value }\end{array}$ & $\begin{array}{l}\text { Weight } \\
\text { Change (kg) }\end{array}$ & $\begin{array}{l}\mathrm{P} \\
\text { Value }\end{array}$ & $\begin{array}{l}\text { Weight } \\
\text { Change (kg) }\end{array}$ & $\begin{array}{l}\mathrm{P} \\
\text { Value }\end{array}$ \\
\hline & $\begin{array}{l}\text { Mean }(95 \% \\
\text { Cl) }\end{array}$ & & $\begin{array}{l}\text { Mean }(95 \% \\
\text { Cl) }\end{array}$ & & $\begin{array}{l}\text { Mean }(95 \% \\
\text { Cl) }\end{array}$ & \\
\hline \multicolumn{7}{|c|}{ COVID-19 induced stress 9} \\
\hline None & Reference & & Reference & & Reference & \\
\hline \multirow[t]{2}{*}{ Mild } & 0.184 & 0.82 & -0.035 & 0.99 & -0.015 & 0.99 \\
\hline & $\begin{array}{l}(-0.309 \text { to } \\
0.677)\end{array}$ & & $\begin{array}{l}(-0.239 \text { to } \\
0.170)\end{array}$ & & $\begin{array}{l}(-0.205 \text { to } \\
0.176)\end{array}$ & \\
\hline \multirow[t]{2}{*}{ Moderate } & -0.320 & 0.73 & 0.049 & 0.99 & -0.025 & 0.99 \\
\hline & $\begin{array}{l}(-1.063 \text { to } \\
0.423)\end{array}$ & & $\begin{array}{l}(-0.259 \text { to } \\
0.356)\end{array}$ & & $\begin{array}{l}(-0.310 \text { to } \\
0.261)\end{array}$ & \\
\hline \multirow[t]{2}{*}{ Major } & 0.213 & 0.96 & 0.039 & 0.99 & 0.056 & 0.99 \\
\hline & $\begin{array}{l}(-0.720 \text { to } \\
0.146)\end{array}$ & & $\begin{array}{l}(-0.341 \text { to } \\
0.418)\end{array}$ & & $\begin{array}{l}(-0.298 \text { to } \\
0.409)\end{array}$ & \\
\hline \multirow[t]{2}{*}{ Severe } & 0.878 & 0.01 & 0.493 & $<$ & 0.551 & $<$ \\
\hline & $\begin{array}{l}(0.149 \text { to } \\
1.607)\end{array}$ & & $\begin{array}{l}(0.130 \text { to } \\
0.816)\end{array}$ & & $\begin{array}{l}(0.254 \text { to } \\
0.847)\end{array}$ & \\
\hline \multirow{2}{*}{$\begin{array}{l}\text { Change in sedentary } \\
\text { time, hr/day }\end{array}$} & 0.530 & $<$ & 0.463 & $<$ & 0.476 & $<$ \\
\hline & $\begin{array}{l}(0.490 \text { to } \\
0.571)\end{array}$ & & $\begin{array}{l}(0.446 \text { to } \\
0.481)\end{array}$ & & $\begin{array}{l}(0.460 \text { to } \\
0.492)\end{array}$ & \\
\hline \multirow[t]{2}{*}{ Depression score } & 0.023 & 0.04 & 0.019 & 0.001 & 0.017 & 0.001 \\
\hline & $\begin{array}{l}(0.001 \text { to } \\
0.047)\end{array}$ & & $\begin{array}{l}(0.008 \text { to } \\
0.030)\end{array}$ & & $\begin{array}{l}(0.007 \text { to } \\
0.027)\end{array}$ & \\
\hline
\end{tabular}

Multivariable model was used to adjust for sex, age, baseline weight, the change in exercise volume, dietary habits (including breakfast and lunch frequency per week, and snacking frequency per day), alcohol, smoking, anxiety score, and all the variables shown in the table simultaneously. Mean variance inflation factors were $1.14,1.15$, and 1.15 for males, females and total analyses respectively.

Data were expressed as weight change associated with increase in sedentary time and depression score.

१ For COVID-19 induced stress, no stress was a reference.

\section{Figures}


A

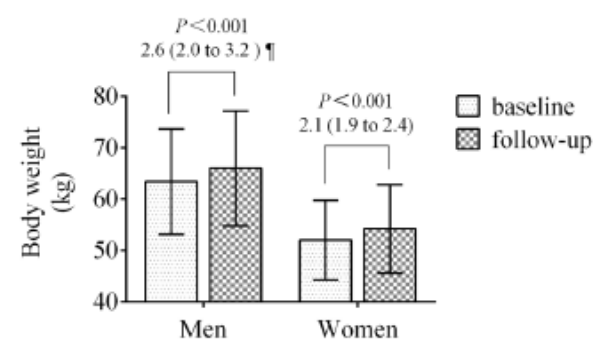

B

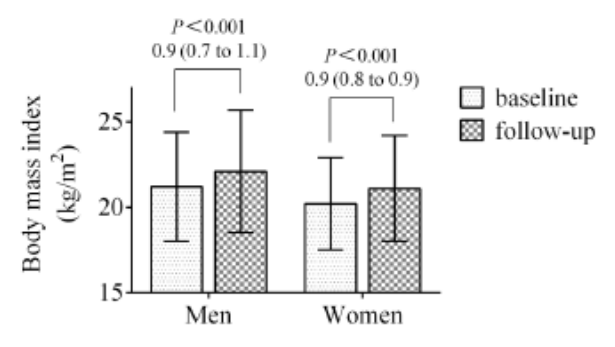

C

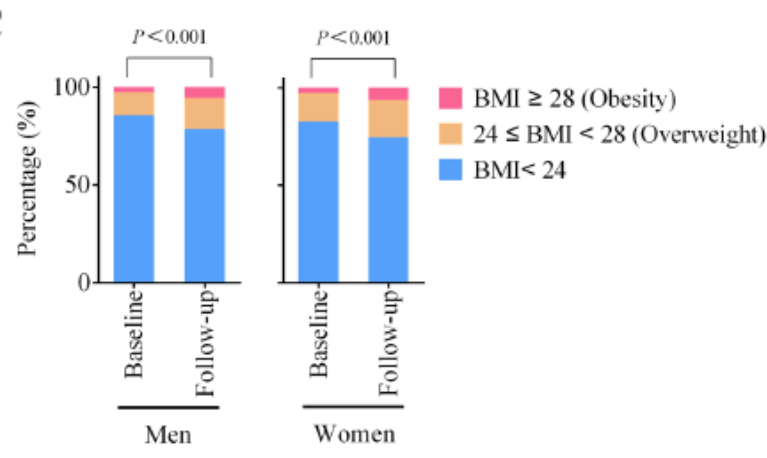

D

E Change in body weight (women)

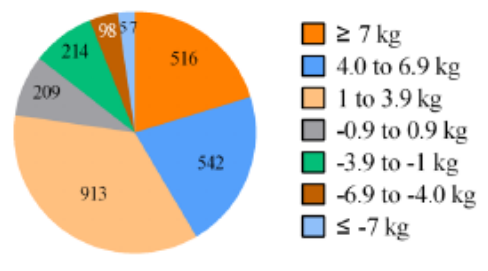

Total $=2,549$

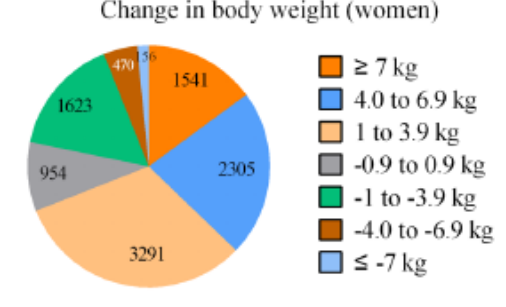

Total $=10,340$

F

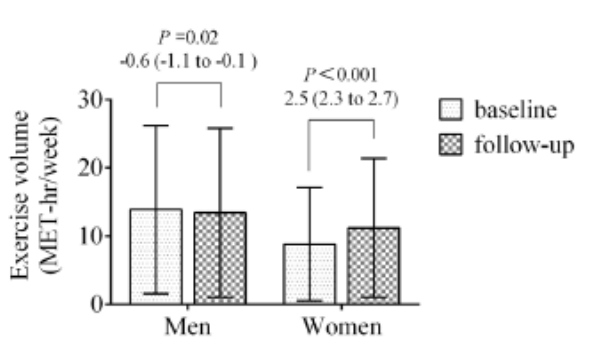

G

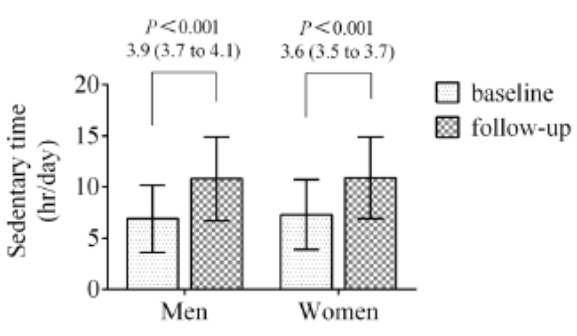

\section{Figure 1}

Changes in body weight (A), body mass index (B), proportion of overweight and obesity (C), gained weight as a proportion in males (D) and females (E), exercise volume per week (F), and sedentary time per day $(\mathrm{G})$ over the 4-month lockdown. Line indicates mean, and error bar indicates standard deviation. 9 Mean difference and 95\% confidence interval. 
A

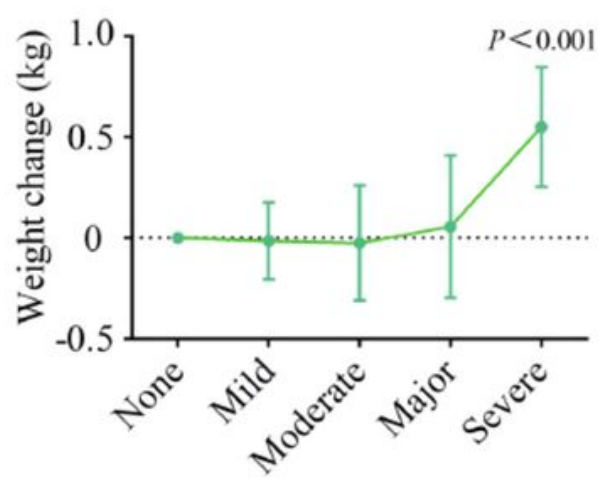

COVID-19 induced stress

B

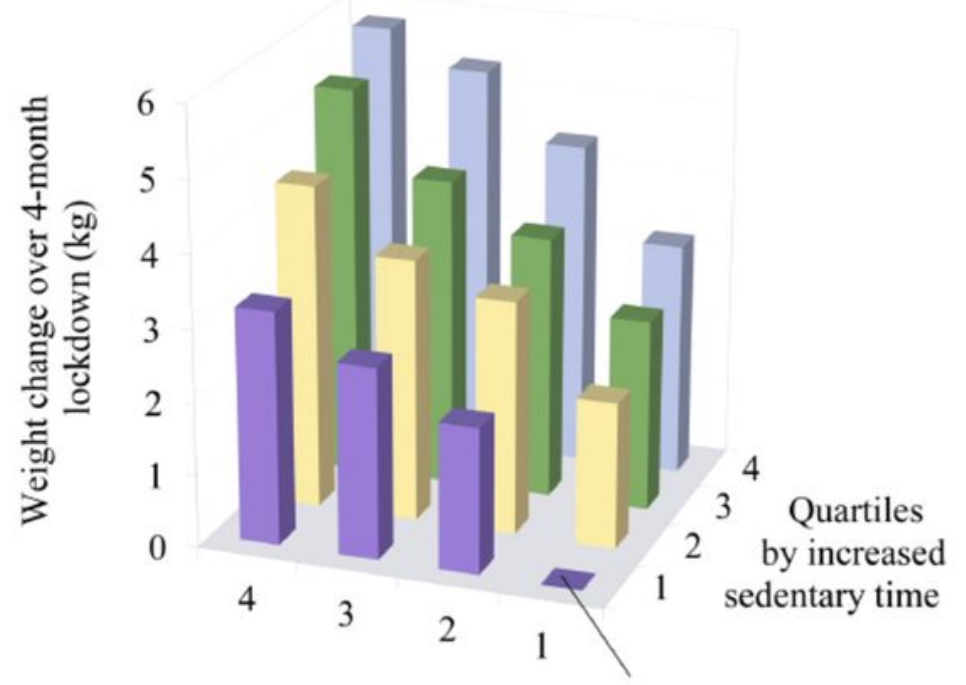

Quatitiles by

Reference depression score

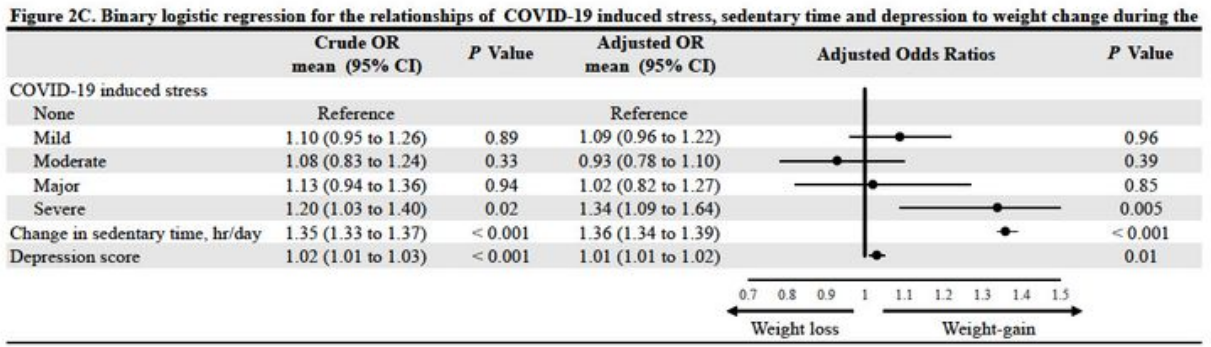

\section{Figure 2}

(A) The relationship between COVID-19 induced stress and weight change, $\mathrm{P}<0.001$ for comparison between no stress and severe stress were. (B) The relationship between the cross-stratified quartiles of changes in sedentary time and depression score in ascending order with weight changes. As compared with individuals in the lowest quartiles of both sedentary time and depression score, individuals in the highest quartiles had a 5.82 kg greater weight-gain ( $P<0.001 ; 95 \% \mathrm{Cl}, 5.37$ to 6.27). There was no 
significant interaction between sedentary time and depression score $(P=0.92)$. All weight changes were adjusted for sex, age, baseline weight, change in exercise volume per week, dietary habits (including breakfast and lunch frequency per week, and snacking frequency per day), alcohol, smoking, anxiety score, and all the variables shown in the figure simultaneously. (C) Multivariable model was used to adjust for sex, age, baseline weight, change in exercise volume, dietary habits (including breakfast and lunch frequency per week, and snacking frequency per day), alcohol, smoking, anxiety score, and all the variables shown in the table simultaneously. Mean variance inflation factor was 1.15 . ( $n=9,108$ subjects with weight-gain, 2,618 with weight loss). $\mathrm{P}<0.001$ for all comparisons.

\section{Supplementary Files}

This is a list of supplementary files associated with this preprint. Click to download.

- supplementaryappendix.pdf 